\title{
Racial Discrimination Reflected on Papua's Dorm in Surabaya
}

\author{
S T Sari ${ }^{1}$, G Bimantara ${ }^{2}$ \\ ${ }^{1,2}$ Airlangga University, Surabaya \\ ${ }^{1}$ sulvianti.tania.sari-2018@,fisip.unair.ac.id, ${ }^{2}$ guruh.bimantara-2018@,fisip.unair.ac.id
}

\begin{abstract}
This final paper discussed about discrimination occurs in the life of Papuanese college student in Surabaya which resulted a mass riot in Papua, Indonesia. In this study, author use data source from newspaper and journal which related to racial discrimination. This study use literal racial discrimination theory by Dovidio (2001). To obtain description regarding discrimination, author would analyze data in the form based on newspaper. In this paper the writer discuss about threw away the flag in the moat. And the student telling about the fact of the flag. It is not like as soldier saw about the problem. And finally TNI fight between Papua student. The discrimination took part on Papua's dorm in Surabaya which conduct a massive turnmoil on Papua Province, Indonesia. It is a problem in this country because it can make apart of Indonesia culture. Beside that it can make of law case because this case related with Human Right. Result of this study showed that there were activity from law enforcement which describe discrimination in various form, such as Explicit Discrimination \& Implicit Discrimination, and Institutional Discrimination \& Cultural Discrimination. Author found the cause of discrimination described in this event, which related with race differences such as differences in skin color, nation of origin and body height.
\end{abstract}

Keyword: Culture, Discrimination, Newspaper, Papua, Racial Discrimination.

\section{INTRODUCTION}

In this paper will described about the racism of the Papua tribe. It is happen in Surabaya, Papua's student have a conflict with TNI. It is happen between student and TNI. This paper basic in newspaper and online news to tell about how the Papua racism happen in Surabaya. It is happen in August $16^{\text {th }}$ and $17^{\text {th }}$. In this case the police detected about 16 eyewitness, 5 TNI suspended and some organization checked. It is happen in Papua's dorm at Jl Kalasan no 10 Surabaya. Caused of this case some student from Papua back to the home, it is about 200 - 300 student back to papua. About 200 student in Manado back to the Papua and some student in Java back to the home.

"yesterday President tell to commander, the fact of government office damaged and racism, it is have no reason, Moeldoko said in president palace complex, Jakarta Thursday August 22 2019. (www.merdeka.com)

From that article as we know the racism happen with TNI and student. Have some papet talk about the racism of Papua student. The first is about TNI and some organization fall the tear gas to the dorm and the second is about verbal bullying. Verbal bullying is about hector to the student example of the hector is about tell of monkey ephitet and other vector happen to student. The writer found about the news about the racism in Papua's student. One of the perpetrator riot in Papua's dorm is Tri Susanti.

From Kompas.com, police said Tri Susanti upload comment in Whatsapp group about discrimination and fake news (hoax). This fake news sending cause protest of flag damaged in Papua's dorm at J1 Kalasan no 10 surabaya.

This paper most to learn about discrimination about the Papua student in Surabaya. Why discrimination and racism happen in Surabaya. This paper will discussing with discrimination theory. It can explain about the discrimination can divided in 2 form, it can show how the writer can see. The writer can catch some message from the dicrimination in Papua's dorm happen. This discrimination include in Institutional Discrimination \& Cultural Discrimination. Because this case show about the organisastion attact the minority tribe. This attact happen to tell bad name to it's like to call monkey and other call. Allport (in Blank \& Dabady, 2004: 56) suggests the steps that lead individuals to act badly on other racial members, these steps are: verbal antagonism (verbal opposition or hostility), avoidance (avoidance), 
interpersonal discrimination (discrimination between individual), physical attack (physical attack), and extermination (murder).

From the news above it can be concluded that the main problem of racism in Papua is the problem of the Republic of Indonesia. According to (Fulthoni., 2009) discrimination is often based on incomprehension in "their" groups. Starting from this lack of understanding, in-group groups often make generalizations about "them". This is where the 'standard setting' of human rights rolled into the amendments to the 1945 Constitution. Where this country is a democracy, every citizen has the same rights and obligations before the law and government. The author chose this topic to be analyzed because the writer is interested in analyzing this into a study because, several problems can be seen from the problems that occur in the discrimination of Papuan students. For example, they have become targets for inappropriate words / vocations. And the second is about how the people underestimate Papuan students who are studying in Surabaya. So this has violated a human right. Where humans are entitled to a decent life as regulated by the preamble of the 1945 Constitution.Tell about maka penjajahan di dunia harus dihapuskan karena tidak sesuai dengan peri kemanusiaan dan peri keadilan. In this case discrimination that occurs to Papuan students can be categorized as cultural discrimination. Because in this discrimination, it can be seen how utterances of hatred can be sent by the perpetrators to make a fuss at the Papuan hostel. So that this problem is very complex. Where the authors find things that result in discrimination from hate speech to deprivation of human rights. So that this issue is very close to the issue of SARA (Inter-Religious Inter-ethnic).

\section{RESEARCH METHOD}

This section would explain about the methodology used in this journal. The method of the study was the application of method in research by the writer

\section{a. Study literature}

Personal experience with discrimination has been linked to elevated rates of deviant peer affiliation, violence, anger, and mental health problems in African -Americans adolescents (Brody, G. H., Chen , Y. Murry, V. M., Ge, X., Simons, R. L., Gibbons, 2006). (Williams, D. R., Neighbors, H. W., \& Jackson, 2003) argues that racial discrimination consist of dominant group members' actions, which are systematic and result in differential and negative effects on subordinate racial/ethnic groups. Discrimination based on race is a phenomenon that many in the white majority class will never have to experience (Feagin, J.R., Vera, H., \& Batur, 2001). (Feagin, J.R., \& Eckberg, 1980) argues that discrimination is evident in activities that disqualify members of one group from opportunities open to others. In other assumption, (Adelman, 2002) said that some form discrimination may result from lack of understanding, socialization or dogmatism while other forms of discrimination may be nurtured and excacerbated by societal events. According to (Corlett. J. A., 2005), racism consist in ethnic prejudice and discrimination. According to (Clough, S., \& Loges, 2008) racism involves obvious false beliefs of superiority or inferiority about a race and its member. (Jones, 2002) argues that institutional racism and discrimination encompasses policies, norms and practices that were historically originated to limit devalued groups access to power and desireable opportunities yet persist because of contemporary structure. (Hannon, 2014) said that personally racism is defined as international and unintentional prejudice like negative assumptions about intelligence and motives and discriminatory actions against devalued groups of color. Racial discrimination defined as a system that disadvantadge particular racial groups, is a distinct risk factor for worse healt outcomes among African Americans (Lewis T, Cogbum C, 2015). From 20 journals the author found several ideas about how discrimination is expressed. It was argued that discrimination is that white people are more profitable than black people because most black people are those who choose to migrate so that they are unemployed (Villarreal, 2010). In the case study which further explains how the oppression of minorities so in this journal it is explained that the suppression of minorities has an impact on mental health that occurs to them (Woods-Giscombé, 2010).

The next study is discrimination about the same discrimination as before, namely about show black and white people are differentiated from work, residence to education. In this case study occurred between America and Africa. Not only influences about residence and others, but in other case studies it was also found that racism will have an impact on behavior, whereas in the previous case study a pafda eye view of a racist had an impact on the reflection of a behavior. But racism is also not only about blacks and whites, here the authors find out about racism and discrimination in handling disease in black people. In this case study explained that this black woman has been discriminated against because of her lupus. In the context of SLE it has been revealed that there are differences in treatment between blacks and white people (Martz, 2019). There is also a difference in an environment between Africa and America, 
where black people are not free to occupy a territory. It can be said that they are isolated from the public, because white people consider this a threat / danger (Brody, G. H., Chen, Y. Murry, V. M., Ge, X., Simons, R. L., Gibbons, 2006). There is also a perception of the negative image of black women in which there is trafficking of women because black women are considered threatening. From studies that have been investigated by the author, it can be investigated that a country that is racist and discriminatory is the United States where they discriminate against black and white people. There are several similarities and differences in discrimination that occur in the case of Papuan students in Indonesia. This section will outline several concepts related to racial discrimination which will become the basis of analysis as well as to answer research questions.

\section{RESULT AND DISCUSSION}

\subsection{Discrimination Theory}

Before entering into an explanation of the definition of discrimination and all its forms, the author will explain the in-group and out-group groups first. In-group and out-group can be found in all communities, even though the interests are not always the same. According to Sumner in-groups are social groups in which individuals identify themselves. (Allport, 2001) itself defines in-group groups as individuals who use the term "we" to show the same interests and characteristics. It is this characteristic and importance that the attitudes of in-group groups are generally based on the factor of sympathy and always have a close feeling with their members. Meanwhile, the understanding of out-group groups according to Sumner is a social group outside the in-group group. Individuals belonging to out-group groups are often considered not to have the same goals or characteristics. Members of a particular group will more or less have a tendency to assume that everything that is included in the habits of the group itself is the best when compared to other groups.

Discrimination often begins with the distinction between "us" and "them". This distinction occurs because humans are social beings who naturally want to gather with individuals who have the same resemblance. According to (Fulthoni., 2009) discrimination is often based on incomprehension in "their" groups. Starting from this lack of understanding, in-group groups often make generalizations about "them". Racial discrimination often results from thoughts and prejudices about differences in physical characteristics. This different treatment and competition between in-group and out-group groups is often the source of discrimination. Discrimination Form (Dovidio, J. F., \& Gaertner, 2004) categorizing discrimination into two forms, namely:

a. Explicit and Implicit Discrimination (clear and subtle discrimination)

b. Institutional and Cultural Discrimination (discrimination in an institution and discrimination regarding culture).

Allport (in Blank \& Dabady, 2004: 56) suggests the steps that lead individuals to act badly on other racial members, these steps are: verbal antagonism (verbal opposition or hostility), avoidance (avoidance), interpersonal discrimination (discrimination between individual), physical attack (physical attack), and extermination (murder). (Dovidio, J. F., \& Gaertner, 2004) argues that a verbal abuse and followed by non-verbal rejection is an indicator of actual discrimination. Avoidance (avoidance) is a further step where in-group members feel comfortable with their group so that a condition will be created in which group members in-group will close themselves from other groups. In social life, in-group groups tend to choose whether to socialize with other groups or not, as this many group members in-group will separate themselves because of racial differences as stated by Johnson and Stafford Institutional and Cultural Discrimination (Discrimination in an Institution and Discrimination Regarding Culture).

\section{CONCLUSIONS}

The conclusion obtained is that discrimination does not only occur in SARA (Inter-Religious Interethnic). But it also happens for human rights, where discrimination can be concluded about how the occupation of human rights that occurs in a person or organization. It can also be concluded that discrimination is not only in violence but also there is a non-verbal discrimination. In sum, a strength of our study is that it addressed explicitly a number of implicit assumptions within the ethnic minority achievement literature regarding the associations among racial identity beliefs, societal racial discrimination, and achievement, and demonstrated the impact of both youths' beliefs and their experiences related to their racial group on their academic engagement. So this paper can described about how the discrimination can divided about NKRI. Our findings challenge the underlying assumption of the risk perspective reflected in much of the research and discourse on racial prejudice and discrimination toward Papuanese student in Surabaya. Additionally, we provided a framework for thinking about the relationship between racial identity and targets for inappropriate words / vocations. 


\section{REFERENCES}

Allport, G. W. (2001). The Nature Of Prejudie Unabridged. (Addison Wesley Publishing Company, Ed.). Menlo Park. London.

Brody, G. H., Chen , Y. Murry, V. M., Ge, X., Simons, R. L., Gibbons, F. X. (2006). Perceived discrimination and the adjustment of African American youths: A five-year longitudinal analysis with contextualmoderation effects. Child Development, 77, 1170-1189.

Clough, S., \& Loges, W. E. (2008). Racist value judgement as objectively false beliefs: a philosophical and social-psychological analysis. Journal of Social Philosophy, 39(1), 77-95.

Corlett. J. A. (2005). Race, racism and reparation. Ithaca: Conell University Press.

Dovidio, J. F., \& Gaertner, S. L. (2004). Aversive racism. In M. P. Zanna (Ed.), Advances in Experimental Social Psychology (Vol. 36, pp. 1-51). San Diego, CA: Academic Press.

Feagin, J.R., \& Eckberg, D. . (1980). Discrimi nation: Motivation, action, effects, and context. Annual Review of Sociology, 6, 1-20.

Feagin, J.R., Vera, H., \& Batur, P. (2001). White racism (2nd ed). New York: Routledge.

Fulthoni., A. (2009). Memahami Diskriminasi. The Indonesia Legal Resource Center. Jakarta.

Hannon, L. (2014). Hispanic respondent intelligence level and skin tone. Hispanic Journal of Behavioral Sciences, 36(3), 265-283. https://doi.org/https ://doi.org/10.1177/07399 86314540126.

Jones, C. P. (2002). Confronting instituzionalized racism. Phylon, 50( 1/2), 7-22.

Lewis T, Cogbum C, W. D. (2015). Self-reported experiences of discrimination and health: scientific advances, ongoing controversies, and emerging issues. Anпu Rev Clim Psychol, 11, 407-440.

Martz, A. et all. (2019). Vicarious Racism Stress and Disease Activity: the Black Women's Experiences Living with Lupus (BeWELL) Study. Journal of Racial and Ethnic Health Disparities, 6, 10441051.

Villarreal, A. (2010). Stratification by skin color in contemporary Mexico. American Sociological Review, 75(5), 652-678. https://doi.org/https :// doi.org/10.1177/0003122410378232

Williams, D. R., Neighbors, H. W., \& Jackson, J. S. (2003). Racial/ethnic discrimination and health: Findings from community studies. American Journal of Public Health, 93, 200-208.

Woods-Giscombé, C. L. (2010). Superwoman schema: African American women's views on stress, strength, and health. Qualitative Health Research, 20, 668-683. https://doi.org/https://doi.org/10. 1177/1049732310361892.

https://www.merdeka.com/peristiwa/kasus-rasisme-mahasiswa-papua-di-surabaya-dua-anggota-tnididuga-indisipliner.html

https://news.detik.com/kolom/d-4690109/solusi-taktis-konflik-papua https://www.cnnindonesia.com/nasional/20190903164442-20-427216/tersangka-rasisme-di-surabayaminta-maaf-kepada-warga-papua https://www.tribunnews.com/regional/2019/08/29/terbaru-kasus-rasisme-mahasiswa-papua-disurabaya-peran-tri-susanti-yang-membuatnya-jadi-tersangka 